\title{
The digerati: Generation $Y$ finds its voice. Why cannot brands do the same?
}

Received: 26th September, 2001

\section{Merlin Stone}

is a specialist in direct and relationship marketing, customer care, customer loyalty, e-business and customer information systems. He is one of the country's top marketing experts and the IBM-sponsored Professor of Relationship Marketing at Bristol Business School. He is now also an Executive Consultant with IBM UK Ltd. He has carried out extensive research into relationship marketing, the deployment of IT systems at the interface with customers as well as sector-specific research into many industries, such as financial services, utilities, automotive, retailing and travel.

\section{Henry Stanton}

began his career at Zinc, working on brands such as Vodafone and Virgin Atlantic. He went on to account manage, among others Virgin Cola, Vodafone and Virgin Atlantic (working on a campaign that won the Precision Marketing Grand Prix in 2000 along the way). In August 2000 he moved to the planning department then onto the Microsoft account. At Holler he is responsible for both new business development and client services.

\section{James Kirkham}

created a touch screen sound installation named 'Holler' with Will Pyne in 1999, gaining a nomination for the New Media Talent awards. He then adapted these skills to the web at Zinc, where he designed Sharwood's and Virgin Cola. In August 2000 James moved to Hard Reality (Hard Reality is now called Leonardo, part of the Leo Burnett Group) where he was a senior designer. At Holler, James heads up the creative department alongside Will Pyne.

\section{Will Pyne}

started out working as a designer at Seven Worldwide. He then moved to Zinc where he produced work for Microsoft and worked with Henry Stanton on the award-winning Virgin Atlantic campaign. His next move was to Travis Sully Harari as senior designer. He subsequently joined James at Hard Reality and he worked extensively on Disney. At Holler, he has been responsible for Universal Music's viral promotions, as well as Mercury Records' campaign for James (the band).

Professor Merlin Stone Executive Consultant, IBM UK Ltd, 76 Upper Ground, South Bank, Mailpoint GSE 1, London SE1 9PZ, UK.

Tel: +44 (0)20 7202 5563; Fax: +44 (0)20 7202 5887; e-mail:

merlin_stone@uk.ibm.com

Abstract This paper investigates the requirements for success in targeting young people. It examines the impact that digital marketing techniques have had upon youth marketing. It explains why digital techniques match the requirements for successful youth marketing in a way in which other media cannot. It concludes with a checklist of do's and don'ts for digital marketing to young people. ${ }^{1}$

Why cannot brands find their voice to speak to youth? It is a valid question the more so because the marketing efforts of youth brands in digital media are questionable in appearance and effect. Their standards of online copy, design and production would never be allowed in a brand's offline presentation.

The digital world should be accepted as the main environment in which a brand communicates with its young market. Most companies, however, under-explore, undervalue and underrate the digital world. The young are confronted with patronising, ill-conceived, generic attempts to engage them. These attempts appear on poorly constructed and maintained websites, dominated by corporate vernacular.

In the valuable youth market, many 
The digerati: Generation $Y$ finds its voice. Why cannot brands do the same?

Table 1: The growing youth market

\begin{tabular}{lccc}
\hline Population (10-14 years), by country (millions) & & \\
\hline Country & $\mathbf{1 9 9 4}$ & $\mathbf{1 9 9 8}$ & $\mathbf{2 0 0 1}$ (estimated) \\
\hline France & 3.86 & 3.84 & 3.82 \\
Germany & 4.48 & 4.59 & 4.68 \\
Italy & 3.10 & 2.90 & 2.77 \\
Netherlands & 0.89 & 0.94 & 0.98 \\
Spain & 2.59 & 2.28 & 2.05 \\
Sweden & 0.48 & 0.54 & 0.58 \\
UK & 3.64 & 3.79 & 3.90 \\
USA & 18.24 & 19.1 & 19.73 \\
Overall & $\mathbf{3 7 . 2 8}$ & $\mathbf{3 7 . 9 8}$ & $\mathbf{3 8 . 6 9}$ \\
\hline
\end{tabular}

Source: Datamonitor analysis

brands ignore the benefits that digital marketing channels offer them. These include cheap customer acquisition, excellent customer loyalty and a level of access to customer data previously unavailable.

\section{WHY MARKETERS SHOULD CARE: THERE IS PLENTY OF MONEY IN THE MARKET}

The following figures illustrate how much money is in the market:

- in the UK there are four million 12 to 16 -year-olds spending $\mathcal{E}^{3} \mathrm{bn}$ annually ${ }^{2}$

- working teens will see their earnings increase by an average of 7.5 per cent year on year ${ }^{3}$

- in 2001 in Germany, 6 to 17-yearolds have 6.5 per cent more money to spend than the year before ${ }^{4}$

- total purchasing power of this group is $\mathrm{E}_{1} 10 \mathrm{bn} \mathrm{n}^{5}$

- the global youth market is now estimated at $\$ 60 \mathrm{bn}^{6}$

- by 2002, the income of online youth across western Europe and the US will be in excess of $\$ 100 \mathrm{bn}^{7}$

- more than one in four seven to ten-year-olds are buying magazines for themselves, while 48 per cent are buying music CDs and 61 per cent tapes. Four years ago, the figures were
23 per cent, 15 per cent and 51 per cent respectively ${ }^{8}$

- the population of ten to 14-year-olds is increasing in size (see Table 1).

Additionally, the power now exerted by this group over their parents' purchasing ('pester power') makes them responsible for an enormous number of household purchasing decisions. In short, this is a powerful consumer group spending in its own way, largely uninfluenced by the very brands that seek to target them, because of the inefficacy of brands' marketing efforts. A smart brand that embraces the digital world in the way suggested here can, however, do very well in this market. If a brand gets the marketing right, the challenge will be to keep up with demand.

\section{SO WHO ARE THESE YOUNG PEOPLE?}

The youth market is traditionally classified into these broad age segments:

$$
\begin{aligned}
& 7-10 \text { (tweens) } \\
& 11-13 \text { (young teens) } \\
& 14-16 \text { (teenagers) } \\
& 16+\text { (young adults) }
\end{aligned}
$$

This approach to segmentation is supposed to allow marketers to target groups with common interests, attitudes 
and desires. Young people, however, might as well be segmented using their inner leg measurements. Age segmentation is a spurious technique. It ignores everything that differentiates young people and is typical of the myopic and flaccid attitudes of most marketers. It is also deeply patronising and guaranteed to turn off any young person who is aware of it. Two years is a lifetime to young people - who went out with someone two years below them at school? It does not happen. Age bands of three years make little sense. Young people should be segmented using criteria such as:

— interests - music, fashion, sport, computer games

- behaviour (active/lazy, gregarious/ anti-social)

— social maturity

- wealth

- location

— ethnic identity

- regional location

— urban vs. rural upbringing

- mobile phone ownership

- school

— online communities

— junk food

- gangs

- gender

- sexuality.

These segments are all based on social factors. There are a few vital statements that can be made about young people across the board, be they eight or 18, short, tall, fat, black, white, shy, orphaned, rich, poor, hard-working, career-driven, celebrity-obsessed, horse mad, football crazy or gay. They are as follows:

- their peer group, and its opinion of them, is very important to them

- they have tight groups of friends, almost tribal in nature (a gang culture is prevalent among many young groups)

- their friends understand them, grow up with them and have earned their trust. They feel their friends are the only people on earth who understand them

- they want more money

- they judge each other on their material possessions

- they want to be seen as cool, and popular

- they aspire to be and try to act older than themselves (because they want respect, independence and the supposed certainties of adult life).

A report from Datamonitor found that to attract young people, websites should be designed to appeal to specific interest groups, not generic age groups. ${ }^{9}$ It is imperative, therefore, that a brand be positioned in a peer group environment. Locating the peer group and communicating with it is difficult, however, as brands cannot provide the same morally vacant environment or accessibility as the peer group. Digital methods can help, however, which is why the digital world must be used as the primary communications device for all brands - it can achieve marketing objectives quicker, more effectively, and with a longer-lasting result than any of the other media.

\section{WHY THIS IS 'NEED-TO-KNOW' FOR EVERY SINGLE BRAND}

Companies that should be trying to market to young people include a wide range of domestic goods suppliers. Traditionally, it was firms supplying goods designed for the youth market that needed to market to young people. This is no longer true, for the reasons outlined below. 


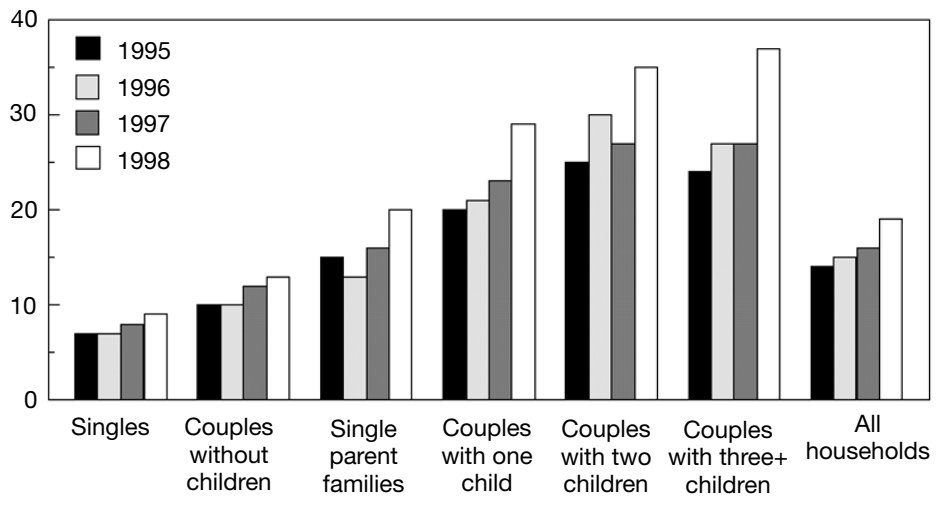

Figure 1 Distribution of computers in France

Young people are going to grow up. Therefore, companies aiming to build brand loyalty among adults must begin that process early. For example, once a consumer has chosen a bank account it is almost impossible to persuade the consumer to move accounts - as grown-ups, individuals are more likely to get divorced than change banks, unless their bank alienates them severely. Teenagers are more fickle, more superficial - they can be won, even bribed. If brand affinity has been developed over a number of years before the age of 16, the likelihood of the consumer staying with that bank for their whole adult life is dramatically increased. Yet banks' efforts in this direction have been really poor. This analogy applies to a massive range of non-youth-oriented businesses, yet few are seriously trying to market to young people. Even fewer are doing it effectively on-line. Many companies are, however, trying. Even Marks and Spencer, famous for its earlier rejection of marketing, has launched its own insurance product range, aimed at both its usual middle-aged market and at its younger customers who own expensive items but do not yet have any insurance brand allegiance. ${ }^{10}$ Interflora have appointed a Youth Marketing Director. BMW are sponsoring a new
MTV show to build brand allegiance from an early age. ${ }^{11}$ Companies are trying to be more sophisticated in their approach - Abbey National has launched a range of youth-focused bank accounts, which, while targeted by age, now defines young people in five specific categories, as opposed to the standard two or three. ${ }^{12}$

Most adults find it hard to adopt new technology - from setting the video recorder to downloading MP3s - young people show their parents how to do it. The young are now the early adopters and key influencers of new technology. Thus, they are the drivers of the new economy. If a family buys a digital television, it can be guaranteed that the children will not only have strongly-held and informed opinions about which television to buy, but also that the parents will not know the difference between digital and analogue television - thus a market is created for adult products by young people. Figure 1 shows the demographic distribution of computers in France. It is those families with children that have the most computers - they are the drivers of new technology adoption.

Young people now have enormous influence over parents' purchasing. In the USA, it is estimated that children aged 


\section{Factors contributing to increased pester power}

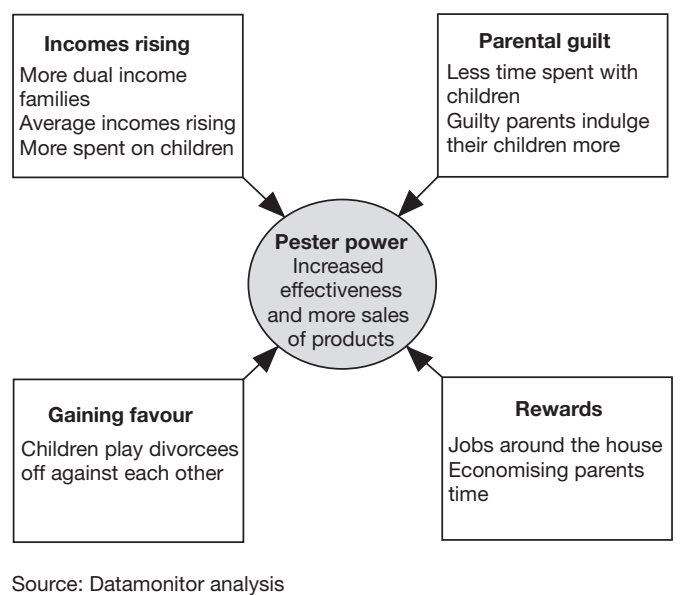

Figure 2 Pester power

4-12 influence family spending of $\$ 188$ bn per year. ${ }^{13}$ Datamonitor analysis explains the rise in pester power in Figure 2. This issue has become so important that in the USA, Time ran a cover story entitled 'Who has the Power?'. It highlighted the extraordinary lengths parents will now go to for their children.

Young people influence not just the buying of products for them. The brand orientation and technical awareness of young people means parents often rely on their offspring to influence or make purchases such as home computers, Internet service providers (ISPs), cars, music, clothes, cosmetics and holidays. As a result, companies are now trying to build brand affinities among young people to gain their parents' custom. Were they effectively marketed to, young people would influence other areas such as financial services, utilities, funeral services, pharmaceuticals, and who knows, perhaps even upholstery and soft furnishings.

Brands are at last taking notice. In the USA, Chevrolet, now sponsors the 'Ripken' Youth Baseball Clinics and summer camps - raising the profile of the Chevrolet name among young people with activities that children enjoy and their parents endorse. It has also partnered with teen apparel brand, Hang Ten, to strengthen its position in the youth market with limited edition vehicles and merchandise. ${ }^{14}$

\section{CONCENTRATE: IT IS NOT THAT DIFFICULT}

Young people must be emotionally engaged. No matter through which channel marketing is taking place, a brand will not succeed unless young people can connect with the brand emotionally, allowing them to trust it. It is that simple. This comes back to the peer group as the key influencer. Just as word of mouth succeeds because of the trust implicit in the communication, the brand must communicate with the young person so as to encourage the young person to trust it. Unless, however, brands allow a young person to feel independent, empowered and free of moral judgments, they will fail to sell to the young person.

'A brand with a price advantage can simply be undercut, a brand with a performance advantage can be outflanked by technical 
development, but a brand with an emotional difference can potentially command a premium for ever.'

\section{WHY DO THIS DIGITALLY?}

Up to this point the paucity of decent youth marketing has been discussed. Why youth marketing should be done mainly online is now explained. Of course, brands should not rely solely on digital channels to communicate their message. Even if digital channels bear the main thrust of the campaign, the full marketing mix should be used to create brand awareness.

Too often the assumption is made that a website means a brand is online and that this means this area of a company's activities can be left alone for the year. So it is also worth outlining what exactly digital channels are. They include:

— websites (and microsites/campaign sites)

— web marketing (e-cards, banner adverts, pop-ups, sponsorship, content partnering, screensavers, desktop toys)

- e-mail

- online chat

- webcasting

— interactive television (sites and adverts)

— short message service (SMS)

- WAP/wireless Internet

- CD-ROMs/enhanced CDs/CD cards

- computer games (console)

- digital radio.

This is obviously a brief list. Not all of them will be appropriate to a campaign. If, however, the basic tenets laid out below are adhered to, a marketer cannot go far wrong.

The brand's activities should add value. Young people are looking for empowerment, entertainment and interaction. Interaction is the key part of this. Their maturing process is driven by a fundamental curiosity about life. This curiosity is satisfied by interacting and communicating; mainly with their peer group. To develop the emotional connection, a brand must allow young people to interact with it. This is where digital channels come to the fore - they allow interaction with an immediacy and vividness that no other channel can offer. MTV is one of the few brands that realise this - they have recently launched a jukebox show where users vote by text message for the song they want played. This is the perfect example of brand interaction - it is immediate, empowering and fun and does not offer any implied moral judgment.

The next point is that not only are most brands falling over themselves to patronise young people, they also bring their own corporate moral values into their marketing. These values have no bearing on the reality of a young person's life and serve purely to illustrate quite how little the brand relates to the young person. As Kate Harrison of Carhartt says, 'A lot of companies think kids are stupid - they think if kids see their stuff everywhere that they'll buy it'. A brand must provide an environment where young people feel they can be themselves. Most young people experience extreme drunkenness. They also know that this will be judged harshly by society. For a brand to gain their trust, young people must feel that it will not judge their drunkenness. This is tough, but the best-positioned youth brands take the role of an older friend - they empower the user and allow them to feel independent while feeling they are not judged. Digital channels can allow even the stuffiest brands to do this. There is no better way for non-youth businesses to communicate with young people without confusing their 'adult' message. Brands have never been able to 
interact with such immediacy or on such a personal level as they have via digital channels.

Digital channels, however, are not just a brilliant method of interaction. They are also very popular with young people: According to an NOP survey, one in four young people aged seven to 16 years said the Internet had replaced television. ${ }^{16}$ In the UK alone, the number of kids using the Internet at home has grown from just over one million at the start of the year to 1.4 million in April. ${ }^{17}$ By 2005, every pupil in Western Europe and the USA will have access to the Internet. ${ }^{18} \mathrm{~A}$ US survey by Roper Starch, found that 63 per cent of young people preferred the Internet to television and 55 per cent rated it above the telephone for communicating with friends. ${ }^{19}$ So it could not be clearer that all consumer brands should create their primary identity in the digital environment. This is where young people can best relate to the brand and so develop the strongest brand affinity. It will not be long before young people are doing more than just surfing the web, new technology will allow them simplified, pre-pay credit cards. Thirty-two per cent of online youth believe that current payment methods inhibit online spending. ${ }^{20}$

\section{AND HERE'S HOW TO DO IT}

Looking at the June, 2001 Datamonitor figures for youth activity online can show how best to approach online marketing (Figure 3).

— get viral: young people talk to each other constantly. They recommend by word of mouth. So whenever a product or service is marketed online, some viral element should be included, to encourage and allow the user to tell their friends
- find out what they like: young people are only too happy to have their details captured if they think they will get something cool in return. So, brand loyalty can be built by capturing data and then regularly communicating with young people, based on preferences they have told the marketer about. This only works, however, if the communication offers something of value. Too many brands send their consumers complete rubbish via SMS or e-mail. This does nothing for the recipient (the user should never be left wondering why they have been sent the message). So, a record company e-mailing users about a new single release must include something of value for the recipient, eg exclusive content about the artist or a game related to the artist. Otherwise the user's trust in both the record company and artist will be broken

- do not treat young people like kids: the best brands avoid moral judgments. For example, the Ministry of Sound website currently has a game where the aim is to throw bricks at people on the current urban scourge, Micro Scooters. This may be morally suspect, but it is highly effective in terms of gaining the user's trust. It also allows the user to interact with the brand and to feel empowered

- entertain: the last thing users want is to find more out about a product.

Entertain them and they connect with the brand. Interactive television games channel, Playjam, reported that a quarter of 16 to 34-year-olds who have access to Sky Digital played a game once during a one-week period $^{21}$

- empower: give users the opportunity to do or say stuff they would not normally be able to. Kellogg's has 


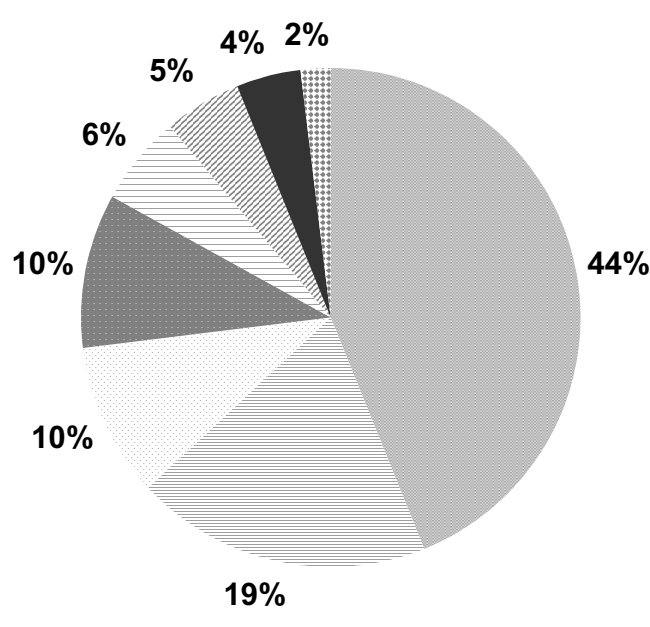

\begin{tabular}{|l|}
\hline Send/Receive email \\
Research/get \\
information \\
Play games \\
Use chat rooms \\
Download music/videos \\
Other \\
Read news/sports/other \\
Shop
\end{tabular}

Figure 3 Teen online activities

developed an online chat system called Chewchat that uses symbols as a means of communicating. When the site was initially launched, Kellogg's was not even mentioned on it. Nor was the name of the product. It was developed organically — offline media involved thousands of stickers of the various symbols being stuck around schools and in playgrounds with the URL www.chewchat.com. In this way, Kellogg's avoided the moral baggage that came with the Kellogg's brand and could develop user loyalty via word of mouth to the Chewchat brand before introducing the new product

- young people actually want to be adults: marketers should try treating them as such.

\section{CAN ALL THE ADVERTISING AGENCIES BE FIRED?}

Of course the other channels are still needed - offline channels should support all digital activity. How and to what extent depends on the product. Where a brand aims to establish a credible presence in young people's minds, below-the-line channels are better than mass media. Young people have seen so many television adverts that they turn off - these advertisements are equated with corporate brands which are not meant for them. It is the guerrilla campaigns that give credibility. Ideally, all the conventional media should push the user towards the digital presence where the user can cement their brand loyalty. Dobedo, an avatar-based chat room facility, launched with a 'street ambient' campaign using radio, cinema, postcards, posters, balloons and beer mats. It led to 170,000 unique users.

Although online work allows the brand to be extended beyond the usual rubbish, it should synchronise with all other elements of the brand:

- product: if the product does not follow the brand in terms of creative, empowerment and lack of implied moral values, it is pointless making the effort in the first place. The young consumer will spot the dislocation immediately and lose any trust in the brand. The product should also 
incorporate the new technologies into its design. They should not just be an add-on. This might be as obvious as creating a computer game that allows the consumer to play online against other people or it could be as sophisticated as a fortune cookie-style sweet where the user sends an SMS containing a number printed on the inside of the sweet wrapper and receives a reply SMS containing the fortune prediction

- pricing: price depends entirely on how good the brand is. Nike is able to charge a premium for trainers because of the strength of their brand. This depends increasingly on how well the brand exploits virtual opportunities

- production process: the brand must extend to the production of the good. If trainers are being made in sweatshops, the brand is destroyed. This illustrates the natural hypocrisy of young people: while despising any moral judgments made about them, they are quick to make them about others.

\section{WHAT NOT TO DO}

1 Pick a URL which is hard to remember.

2 Create a link to the youth site off the main corporate site.

3 Re-purpose existing content on to the website (eg television adverts).

4 Just offer a flash site (young users at school may not be able to download the plug-in).

5 Offer an empty chat facility instead seed message board discussions or maintain a certain number of users in any chat room.

6 Offer any implied moral judgments.

7 Write copy in the style you believe young people talk.

8 Target a specific age group with the site and expect all other age groups to trade up/down - specific sites should be provided for each target (not age) group.

9 Capture user's details and then spam them without offering any value.

10 Launch the site early and promise lots of content soon - no-one will return.

\section{TRY IT, YOU MIGHT JUST LIKE IT}

1 Moderate any chat facility.

2 Ensure the brand has done its best to discourage paedophiles from using any chat facility.

3 Partner with respected online youth brands, eg Worldpop.com.

4 Run quick-win SMS-based competitions (they cannot fail).

5 Offer interactive elements to the site (not just content heavy).

6 Offer original content (if content from Smash Hits is re-purposed, the users will know because they have all read it already).

7 Allow users to define as much of their activity on the site as possible.

8 Regularly update content and games (otherwise users will not return).

9 Communicate with users if they have given their details (do not leave it months before sending the first newsletter).

10 Respond within 24 hours to any unprompted communications from users otherwise they will not return and they will never trust the brand again.

\section{AND WE'RE DONE}

It is not the easiest thing in the world, but marketing to young people can earn a lot of money. Many companies ignore the power of young money and the influence young people have over their 
parents' purchasing. It is easier to do in an online environment. The principles in this paper must be upheld when marketing to young people (eg do not be patronising, do not segment on the basis of age) whether marketing on- or offline. If these principles are followed and if the brand's online presence is well executed, the brand cannot fail.

\section{References}

1 Authors' note: This paper has been partly written by young suppliers of youth marketing services - so the style is not that conventionally followed in this journal, but one which would be used to address young marketers.

2 Netimperative.com, 3rd February, 2000.
3 'Personal care: Targeting the youth market', Datamonitor, July, 2000.

4 Kids Consumer Analysis 2001, Verlagsgruppe Lubbe, Bauer Verlagsgruppe and Axel Springer Verlag.

5 Ibid.

6 Datamonitor (2000) op. cit.

7 Ibid.

8 Kids Marketing Report, 24th November, 1998.

9 Datamonitor, July, 2001.

10 Precision Marketing, 18th May, 2001.

11 Mad.co.uk, 8th June, 2001.

12 New Media Age, 20th July, 2001.

13 Kids Marketing Report, 3rd October, 2000.

14 Kids Marketing Report, 2nd May, 2001.

15 Cowley, D. (1996) 'Understanding brands'.

16 Netimperative, 23rd December, 1999.

17 Kids Marketing Report, 5th June, 2001.

18 Datamonitor (2000) op. cit.

19 Netimperative (1999) op. cit.

20 Datamonitor (2000) op. cit.

21 New Media Age, 12th April, 2001. 